\title{
The Impact of Ischemia and Reperfusion Injury in Kidney Allograft Outcome
}

\author{
Valquiria Bueno \\ UNIFESP - Federal University of São Paulo \\ Brazil
}

\section{Introduction}

Acute kidney injury (AKI) is characterized by a relatively sudden decrease in the production, processing, and excretion of ultrafiltrate by the kidney (decrease in glomerular filtration rate - GFR). Acute kidney injury (AKI) caused by ischemia and reperfusion injury (IRI) is a common event in transplantation and $20 \%$ to $80 \%$ of kidneys from deceased donors can present delayed graft function (DGF) depending on the injury extent (Perico et al., 2004). After transplantation it could be expected immediate renal function, slow recovery function, non-oliguric acute tubular necrosis (ATN), total anuria. Delayed graft function (DGF) is defined by transplant centers as: the need of dialysis (at least one session) during the first week post-transplantation (Koning et al., 1997), early urine output lower than $1200 \mathrm{~mL} /$ day or no decrease in serum creatinine within $48 \mathrm{~h}$ (Shoskes et al., 2001), creatinine clearance lower than $10 \mathrm{~mL} / \mathrm{min}$ (Giral-Classe et al., 1998), creatinine at day 10 higher than $221 \mu \mathrm{mol} / \mathrm{L}$ (Cosio et al., 1997).

Delayed graft function has been considered an independent predictor of graft loss since multivariate analysis showed a relative risk of graft loss 2.9 times greater for DGF than for kidneys with immediate function (Halloran et al., 1988). The US Renal Data System $(37,000$ primary cadaver transplants) showed a relative risk of 1.53 for 5-year graft loss in association with DGF (Ojo et al., 1997). In cadaver transplants (1994-1998 in USA) the halflife of kidneys with DGF was 7.2 years whereas in kidneys with immediate function it was 11.5 years (Halloran et al., 2001). In the presence of rejection DGF's effect is even stronger and kidney graft half-life decreases from 9.4 to 6.2 years (Shoskes et al., 1998). Kyllönen et al. (2000) showed in a follow-up of 1047 cadaveric kidney transplants performed at University of Helsinki that 5-years graft survival was $60 \%$ in patients presenting DGF and rejection, $73 \%$ in patients with rejection, $77 \%$ in patients with DGF and $88 \%$ in patients without both risk factors. They concluded that DGF was a significant factor affecting long-term graft survival, both through and independent of acute rejection. In 10-years of transplantation follow-up Troppman et al. (1999) observed 64\% of graft survival in patients without DGF or rejection episodes, $44 \%$ in patients with DGF, $36 \%$ in patients with rejection, and $15 \%$ in patients presenting both risk factors.

A range of factors could lead to DGF such as organ procurement (i.e. kidneys from nonheart-beating donors), donor characteristics (i.e. donors older than 55 years), period of ischemia, recipient historic (i.e. number of recipient's previous transplants), renal toxicity, ureteral obstruction, among others. Since DGF is considered an independent risk for graft 
loss and one of the factors inducing DGF is ischemia and reperfusion we will focus this chapter on the impact of ischemia and reperfusion in kidney allograft outcome.

\section{Ischemia and reperfusion injury}

Nankivell \& Chapman (2006) conclude in their review that kidney damage after transplantation is mediated by alloimune, ischemic and inflammatory stimuli causing tubular injury in association with profibrotic healing response. In addition to the changes in kidney histology be multifactor post-transplantation, the underestimation of this organ injury by serum creatinine measurement make complex the dissection of the steps during kidney damage. Therefore, biopsy histology is still the gold standard technique to evaluate clinical kidney damage after transplantation. Sequential studies of biopsies show early tubulointerstitial damage followed by later microvascular and glomerular changes with progressive fibrosis and atrophy (Solez et al., 1998; Kuypers et al., 1999, Cosio et al., 1999).

Tubulointerstitial damage begins soon after transplantation due to ischemia-reperfusion injury and the resolution of this process is crucial for kidney outcome. The tubulointerstitium is an essential component of a functioning kidney as it accounts for $95 \%$ of a kidney by weight, performs almost all of the metabolic work, and is responsible for salt and water balance, potassium excretion, acid-base control, small protein catabolism, and hormone production such as erythropoietin (Nankivell et al., 2003).

The major events affecting the tubulointerstitium are listed as it follows:

- Oxygen deprivation due to ischemia induces early ATP depletion which stops ATPdependent transport pumps, resulting in mitochondrial swelling. Mitochondrial swelling results in outer membrane rupture, with release of mitochondrial intermembrane proteins. Caspase 1 or interleukin- 1 converting enzyme (ICE) cleaves interleukin (IL)-1b. IL-1b is a pro-inflammatory cytokine, and can induce renal tubular epithelial cells to secrete chemokines such as keratinocyte-induced chemoattractant (KC), macrophage inflammatory protein (MIP)-1a, or RANTES (Furuichi et al., 2002).

- Hypoxia inducible factor (HIF-1, HIF-2, HIF-3), HIF-3 may be a negative regulator of hypoxia-inducible genes expressed by HIF-1 and HIF-2 (Nangaku et al., 2008). HIF-1 is unstable under normal conditions but it is stable and works under hypoxic conditions (Huang et al., 1996; Salceda \& Caro, 1997). Many genes encoding for cytokines and growth factors are induced by HIF-1 activation (El Awad B et al., 2000; Zhou \& Brune, 2006).

- Oxygen-derived free radicals and in particular hydrogen peroxide, which is a source of oxygen-derived free radicals after IR injury, has been reported to induce TNF- $\alpha$ production by activating p38 mitogen-activated protein kinase (MAPK) (Meldrum et al, 1998).

Ischemia injury begins with the cessation of arterial blood flow and immediate oxygen deprivation in cells (i.e., hypoxia with accumulation of metabolic products). In the kidney, decreased blood supply is associated with flow diversion from cortex to medulla which preserves oxygenation of the metabolically vulnerable medulla at the expense of cortical perfusion and glomerular filtration (Woolfson et al., 1994). Sensitivity to hypoxia or ischemia has been demonstrated in both proximal tubules (Shanley et al., 1986) and their thick ascending limbs (Brezis et al., 1985).

Severe reduction of renal blood flow causes cell damage both by the high-energy phosphate depletion and the subsequent failure to maintain physiological ion gradients across the cell 
membrane. However, the major injury to the ischemic organ occurs during the reperfusion phase in which the blood flow returns to the ischemic tissue. Reperfusion is associated with free radical generation leading to lipid peroxidation, polysaccharide depolymerization and deoxyribonucleotide degradation. Injured endothelial cells fail to vasodilate underlying vascular smooth muscle, release potent vasoconstrictors and swell which leads to increased permeability (Woolfson et al., 1994).

Following kidney IRI, the coordinated action of cytokines/chemokines, reactive oxygen intermediates and adhesion molecules causes a cascade of events leading to endothelial cell dysfunction, tubular epithelial cell injury and activation of both tissue-resident and kidney infiltrating leukocytes (Bonventre \& Weinberg, 2003; Li \& Okusa, 2006).

\subsection{Kidney-resident cells can express markers of activation and thus generate inflammatory responses}

Toll-like receptors (TLRs) are a family of transmembrane proteins expressed in monocytes, macrophages, dendritic cells, T-and B cells, and neutrophils. TLRs expression by primary culture of mouse cortical renal epithelial cells was first reported by Tsuboi et al. (2002). Renal tubule cells from mouse, rat, and human have been shown to express TLR2 and TLR4 (Wolfs et al., 2002; Yang et al., 2006; Chowdhury et al., 2006; Chassin et al., 2006; Shigeoka et al., 2007; El-Achkar et al., 2006; Bäckhed et al., 2001; Samuelsson et al., 2004). The activation of TLRs can be initiated by pathogens and also by a "sterile" inflammatory process mediated by DAMPs (damage associated molecular pattern molecules). DAMPs are endogenous constituents released by damaged/necrotic cells (heat shock proteins, high mobility group box 1 - HMGB1, fibronectin, heparan sulfate, hyaluronic acid) and components of the extracellular matrix released by proteases to which TLR2 and TLR4 bind.

TLR2 and TLR4 constitutively expressed in resident kidney cells are upregulated after IRI (Wolfs et al., 2002; Kim et al., 2005). TLR cell surface activation triggers an intracellular cascade of events resulting in the release of NF- $\kappa \mathrm{B}$ from $\mathrm{I} \kappa \mathrm{B}$, allowing NF- $\kappa \mathrm{B}$ to translocate from cytoplasm to the nucleus and mediate an increase in inflammatory genes expression which leads to pro-inflammatory responses (Liew et al. 2005; O'Neill, 2006).

Lassen et al. (2010) propose that ischemia reperfusion-induced reactive oxygen species (ROS) activates tubular epithelial cells to release DAMPs which activate TLRs signaling and the subsequent production of proinflammatory cytokines and chemokines either by intrinsic renal cells and intrarenal antigen presenting cells (APCs). As a consequence leukocytes are attracted to the kidney, accumulate in this site, get activated and produce pro-inflammatory cytokines. (Li et al., 2007; Kelly et al., 1996; Wu et al., 2007; Kielar et al., 2005).

IRI causes damages in endothelial cells which in turn increase vascular permeability (Sutton et al., 2003; Brodsky et al., 2002) and the expression of adhesion molecules (Kelly et al., 1996) contributing thus for leukocyte migration to the kidney. Both E-selectin and intercellular adhesion molecule-1 (ICAM-1) on peritubular capillary cells play crucial roles in IRI.

Mice submitted to 32 minutes of bilateral renal pedicles clamp showed a maximum kidney E-selectin expression 24 hours later when renal tissue was evaluated by Western blot. Moreover, the immunostaining localized E-selectin in the endothelium of the peritubular capillary plexus. Administration of anti-E-selectin or use of E-selectin deficient mice was 
associated with lower creatinine concentrations at 24 hours indicating a potential therapeutic perspective for this molecule (Singbartl \& Ley, 2000).

The evaluation of 49 renal transplant patients with mean cold ischemia time of 27 hours showed that 3 minutes after kidney graft reperfusion the renal vein presented concentrations of E-selectin, VCAM and ICAM which correlated positively with hypoxanthine concentrations. This correlation may be associated with the release of hypoxanthine by the graft as an ischemia marker reflecting metabolic changes in renal tissue during reperfusion (Domanski et al., 2009).

The inflammatory microenvironment in the kidney is closely associated with the functional and structural renal changes occurring in this organ after IRI.

\subsection{Cells associated with IRI}

\subsubsection{Dendritic cells}

Dendritic cells (DCs - CD11c $\mathrm{c}^{+}$) and class II major histocompatibility complex (MHC Class II) ${ }^{+}$DCs are the most abundant leukocyte subset residing in the normal mouse kidney (Li et al., 2008; Soos et al., 2006) suggesting an important role in renal immunity and inflammation. TNF-a, IL-6, MCP-1 and RANTES (pro-inflammatory cytokines/chemokines) are produced by renal DCs after IRI, and depletion of DCs prior to IRI significantly reduced the kidney levels of TNF-a (Dong et al., 2007).

\subsubsection{Neutrophils}

Neutrophils inhibition has been shown in some studies to attenuate renal injury after IRI (Kelly et al., 1996), whereas other studies failed to find a protective effect of neutrophil blockade or depletion (Thornton et al., 1989). Many factors affecting neutrophil infiltration or activation including neutrophil elastase, tissue-type plasminogen activator, hepatocyte growth factor, and CD44 have been suggested to contribute for the renal damage following IRI (Hayama et al., 2006; Roelofs et al., 2006; Mizuno et al., 2005; Rouschop et al., 2005). Despite discrepancies in data provided by different research groups, it is likely that neutrophils participate in inducing renal injury by plugging renal microvasculature and releasing oxygen-free radicals and proteases.

\subsubsection{Macrophages}

Macrophages infiltrate the injured kidney early within 1 hour of reperfusion, and this infiltration is mediated by CCR2 and $\mathrm{CX}_{3} \mathrm{CR} 1$ signaling pathways (Oh et al., 2008; Li et al., 2008). Analysis of kidney infiltrating macrophages by flow cytometry demonstrated that these leukocytes are significant producers of the cytokines IL-1a, IL-6, IL-12p40/70 and TNF-a (Li et al., 2008).

\subsubsection{Natural Killer}

Natural Killer (NK) cells have recently been reported to infiltrate the post-ischemic kidney by 4 hours of reperfusion. IRI induced the expression of an NK cell-activating ligand (Rae-1) on tubule epithelial cells (TECs) and in vitro studies demonstrated that the interaction of the NKG2D receptor on NK cells with Rae-1 on TECs causes perforin-dependent lysis of cultured kidney cells. Antibody-mediated depletion of NK cells inhibited IRI in wild-type (WT) mice and adoptive transfer of WT, but not perforin KO, NK cells into a T, B and NK cell-deficient mouse enhanced IRI (Zhang et al., 2008). 


\subsubsection{Invariant Natural Killer T}

Invariant Natural Killer T (iNKT) cells are a unique subset of T lymphocytes with surface receptors and functional properties shared with conventional T cells and NK cells. In contrast to conventional T cells, iNKT cells are activated by endogenously released glycolipid antigens. A recent finding is that the number of IFN-ү-producing iNKT cells in the kidney is significantly increased by 3 hours of reperfusion compared to sham-operated mice. Also, blockade of NKT cell activation with the anti-CD1d mAb, NKT cell depletion with an antiNK1.1 mAb in WT mice, or use of iNKT cell deficient mice (Ja18/-) inhibited the accumulation of IFN- $\gamma$-producing neutrophils after IRI and prevented AKI (Li et al., 2007).

\subsubsection{T lymphocytes}

In the early stage of IRI, $\mathrm{T}$ cells may become activated through antigen-independent mechanisms by inflammatory cytokines and reactive oxygen intermediates (Bacon et al., 1995). T cell trafficking was observed as early as $1 \mathrm{~h}$ after IRI and decreased at $24 \mathrm{~h}$ following IRI (Noiri et al., 2009; Ascon et al., 2006). T cell recruitment influences proinflammatory cytokine production, neutrophil trafficking, and progression to fibrosis (Burne et al., 2001). Moreover, T cells also influence vascular permeability in early ischemic AKI (Saito et al., 2009). Increased numbers of activated and effector-memory $T$ cells were found in the postischemic kidneys as late as 6 weeks after IRI, suggesting that T cells are also involved in long term structural changes of postischemic kidneys (Ascon et al., 2008).

\subsection{Histology changes in kidney after IRI}

IRI is associated with several complexes events such as negative impact in capillary density (Basile et al., 2001) and increase of the vascular permeability which interferes with the protective barrier among circulating elements and parenchyma cells. These factors induce the no-reflow phenomenon and leads to inflammation (Cicco et al., 2005; Sutton TA, 2009).

Jayle et al. (2007) showed that in pig kidney autotransplant model the development of chronic fibrosis and subsequent renal failure were associated with the severity of IRI with more damage occurring in kidneys submitted to 60 or 90 minutes of IRI than to 45 minutes. Using the same model Thuillier et al. (2010) evaluated 60 minutes of renal pedicle clamping, kidney removal and preservation for 24 hours in UW solution followed by autotransplantation and showed that 3 months later the GFR was still significantly lower and the proteinuria was increased. Grafts presented a significant amount of interstitial fibrosis and tubular atrophy besides of T and ED1+ cells infiltration. Authors concluded that IRI has the ability to induce chronic adaptive inflammation response, even in autologous grafts. Moreover, even 6 weeks later of prolonged ischemia (unilateral renal pedicle clamp for 60 minutes) in the absence of transplantation it was possible to observe kidney shrunken in size with loss of tubular architecture (dilatation of tubules and cyst formation). It was also found infiltration of phagocytes, neutrophils and $\mathrm{T}$ cells suggesting long-term kidney inflammation (Burne-Taney et al., 2005).

Williams et al. (1997) showed that rats submitted to 45 minutes of bilateral renal pedicle clamp presented a peak of increased serum creatinine 24 hours later which was in accordance with the highest renal myeloperoxidase activity (and indicator of neutrophil infiltration) and massive amount of proximal convoluted tubule cells necrosis. Despite the return of creatinine to normal levels at 1 week later, atrophic tubules and focal fibrosis were still observed suggesting permanent tubular loss. 
It has been shown that hypoxic stress induces apoptosis of renal proximal tubular cells via mitochondria-dependent and -independent pathways, partly by activation of caspase-3 (Edelstein et al., 1999). Clinical and experimental models demonstrate that immunosuppressive drugs can impair tubular cells proliferation in replacement to those in apoptosis.

Lui et al. (2006) observed that mice treated with Rapamycin from day -1 and submitted to 45 minutes of bilateral renal pedicles clamping presented 24 hours later significantly increased levels of creatinine. Moreover, renal tubular cells showed generalized swelling and vascuolization besides of very low numbers of PCNA-positive nuclei cells. These factors were normalized on day 3 except for PCNA which increased only on day 7 suggesting that early after IR Rapamycin impairs renal function and retards the proliferative response of the renal tubular cells.

Sirolimus exposure in recipients of cadaveric kidneys (mean of cold ischemia time $=20$ hours) experiencing DGF showed strong association with prolonged time for the recovery of the graft function. This finding indicates that sirolimus impairs the kidney's ability to recovery from injury (McTaggart et al., 2003).

Novick et al. (1986) showed that cadaveric transplants with mean preservation time of 37 hours presented one-year actuarial graft survival of 78\% in ALG (azathioprine - prednisone - antilymphocyte globulin) versus $48 \%$ in CsA (prednisone- cyclosporine) immunosuppressive protocol. The difference was attributed to the large number of primary nonfunctioning grafts in CsA group probably due to the effect of CsA's nephrotoxicity superimposed on renal ischemia incurred prior to transplantation.

\subsection{Ischemic acute kidney injury (AKI) influences the choice of the immunosuppressive therapy after transplantation}

Nankivell et al. (2003) evaluated biopsies of 120 patients maintained on Cyclosporine-based immunosuppression 5 years post-transplantation and found that $66 \%$ of them presented moderate-to-severe interstitial fibrosis and $90.3 \%$ presented arteriolar hyalinosis. Authors proposed two phases of chronic allograft nephropathy: an early fibrogenic phase attributed to ischemia-reperfusion injury and a late phase with fibrosis and arteriolar hyalianosis generated by cyclosporine (CsA) toxicity. On the other hand, Stegall et al. (2010) showed in 296 biopsies that the prevalence of moderate/severe histology changes at both 1 and 5 years post-transplantation was less than $20 \%$ including fibrosis and hyalinosis in recipients treated with a triple therapy (Tacrolimus, MMF and Azatioprine, or Sirolimus in the CNI-free protocol). Authors also found that the most important variable associated with moderate/severe fibrosis at 5 years was delayed graft function (DGF).

Despite of the controversy in how significant is the hazard added by the immunosuppression (past immunosuppressive protocols versus new immunosuppressive era) to the kidney function and histology it seems to be a consensus that DGF is an independent risk at any of the immunosuppressive protocols evaluated. This has been confirmed recently by Snoeijs et al. (2011) in MMF or SRL protocols when 8 recipients of kidneys from deceased donors with ischemia and reperfusion injury (DCD) were compared with 8 recipients of kidneys from living donors with minimal ischemic injury (LD). Delayed graft function was $70 \%$ in recipients of DCD kidneys whereas $100 \%$ of patients receiving LD kidneys showed immediate graft function. Creatinine clearance was significantly lower in recipients of DCD kidneys than in recipients of LD kidneys whereas the fractional excretion 
of sodium was higher in DCD group. In addition, kidneys from DCD donors presented post-transplantation early necrotic tubular epithelial cell death and systemic immune response activation.

Boratynska et al. (2008) showed that patients receiving kidney transplants with cold ischemia time longer than 24 hours and treated with a SRL (SRL + CsA + Prednisone, $n=23$ ) or CsA (Azathioprine + CsA + Prednisone, $n=23$ ) protocol presented DGF in 39\% and 35\% of cases respectively. Moreover, the duration of DGF and the decrease in serum creatinine were prolonged in the SRL protocol whereas biopsies from both groups presented loss of the brush border in tubular epithelial cells. One and 5-year graft survival were $100 \%$ and $87 \%$ in SRL and $95 \%$ and $74 \%$ in CsA protocols showing improved renal graft survival in patients treated with SRL. Serum creatinine level at the $12^{\text {th }}$ month was higher in patients with DGF independent of the immunosuppressive protocol.

Experimental models have contributed extensively to the better knowledge in IRI, immunosuppressive regimen and kidney damage. Moreover, clinical findings are in line with experimental models as it follows:

Ninova et al. (2004) showed in a rat model that at early time point (14 days) few signs of nephrotoxicity developed when unilateral nephrectomy was performed and animals were treated with Tacrolimus or Sirolimus. However, when kidneys were submitted to IRI due to transplantation, there was increase in serum creatinine, interstitial fibrosis, vacuolization and inflammation. It was also found, intragraft expression of TGF- $\beta$ and a-SMA indicating a profibrotic environment. These results suggest that IRI plays a significant role in druginduced nephrotoxicity.

Delbridge et al. showed that rats submitted to monolateral renal clamp for 45 minutes and nephrectomy of the contrateral kidney presented 30 days later a serum creatinine (SCr) still significantly higher than control rats. The treatment with FTY720 alone $(1 \mathrm{mg} / \mathrm{kd})$ decreased SCr to control levels while CsA $(15 \mathrm{mg} / \mathrm{kg})$ potentiated the increase in SCr. However, the decrease in SCr was observed when FTY720 was administered in association with CsA suggesting a protective effect for the treatment with FTY720. The same was observed for proteinuria, kidney fibrosis and levels of serum TGF- $\beta 1$ (Delbridge et al., 2007). Using the same model and treating rats with MMF $(20 \mathrm{mg} / \mathrm{kg} / \mathrm{d})$ Sabbatini et al. (2010) showed 6 months after IRI that the glomerular filtration rate (GFR) was similar when non-treated animals $(\mathrm{GFR}=0.50)$ were compared with those treated with MMF (GFR=0.49) which was significantly lower than in normal uninephrectomized animals (GFR=0.87). Even though MMF significantly reduced the early kidney inflammatory process, renal histology in treated rats was similar to that of untreated animals showing $28 \%$ and $34 \%$ respectively of tubular necrotic cells.

\section{Conclusion}

Ischemia reperfusion injury is a common event in kidney cadaveric transplantation and leads to delayed graft function. The choice of the immunosuppressive protocol should consider that the early administration of drugs such as CNIs and Sirolimus could retard the recovery of kidney function and structure.

\section{Acknowledgements}

Financial support FAPESP and CNPQ 


\section{References}

Ascon M, Ascon DB, Liu M et al. (2008). Renal ischemia-reperfusion leads to long term infiltration of activated and effector-memory $\mathrm{T}$ lymphocytes. Kidney International 75:pp.526-535, ISSN 0085-2538

Ascon DB, Lopez-Briones S, Liu M, Ascon M, Savransky V, Colvin RB, et al. (2006). Phenotypic and functional characterization of kidney-infiltrating lymphocytes in renal ischemia reperfusion injury. The Journal of Immunology 177:pp. 3380-3387, ISSN 1550-6606

Bäckhed F, Söderhäll M, Ekman P, Normark S, Richter-Dahlfors A. (2001). Induction of innate immune responses by Escherichia coli and purified lipopolysaccharide correlate with organ- and cell-specific expression of toll-like receptors within the human urinary tract. Cell Microbiology 3: pp. 153-158, ISSN 1462-5822

Bacon KB, Premack BA, Gardner P, Schall TJ. (1985). Activation of dual T cell signaling pathways by the chemokine RANTES. Science 269: pp. 1727-1730, ISSN 1095-9203

Basile DP, Donoheo D, Roethe K, et al. (2001). Renal ischemic injury results in permanent damage to peritubular capillaries and influences long-term function. American Journal of Physiology Renal Physiology 281: pp. F887-F899, ISSN 1522-1466

Blydt-Hansen TD, Gibson IW, Birk PE. (2010). Histological progression of chronic renal allograft injury comparing sirolimus and mycophenolate mofetil-based protocols. A single-center, prospective, randomized, controlled study. Pediatric Transplantation 14: pp. 909-918, ISSN 1397-3142

Bonventre JV, Weinberg JM. (2003). Recent advances in the pathophysiology of ischemic acute renal failure. The Journal of American Society of Nephrology 14: pp. 2199-2210, ISSN 1533-3450

Boratynska M, Banasik M, Patrzalek D, Klinger M. (2008). Impact of sirolimus treatment in kidney allograft recipients with prolonged cold ischemia times: 5-year outocomes. Experimental and Clinical Transplantation 6: pp. 59-66, ISSN 1304-0855

Brezis M, Shanley P, Silva P et al. (1985). Disparate mechanisms for hypoxic injury in different nephron segments. Studies in the isolated perfused rat kidney. Journal of Clinical Investigation 76: pp. 1796-1806, ISSN 0021-9738

Brodsky SV, Yamamoto T, Tada T, Kim B, Chen J, Kajiya f, Goligorsky MS. (2002). Endothelial dysfunction in ischemic acute renal failure: rescue by transplanted endothelial cells. American Journal of Physiology Renal Physiology 282: pp. F1140F1149, ISSN 1522-1466

Burne-Taney MJ, Yokota N, Rabb H. (2005). Persistent renal and extrarenal immune changes after severe ischemic injury. Kidney International 67: pp. 1002-1009, ISSN 0085-2538

Burne MJ, Daniels F, El Ghandour A, Mauiyyedi S, Colvin RB, O'Donnell MP, et al. (2001). Identification of the CD4 T cell as a major pathogenic factor in ischemic acute renal failure. Journal of Clinical Investigation 108: pp. 1283-1290, ISSN 0021-9738

Chassin C, Goujon HM, Darche S, du Merle L, Bens M, Cluzeaud F, Werts C, Ogier-Denis E, Le Bouguénec C, Buzoni-Gatel D, Vandewalle A. (2006). Renal collecting duct epithelial cells react to pyelonephritis-associated Escherichia coli by activating distinct TLR4-dependent and -independent inflammatory pathways. The Journal of Immunology 177: pp. 4773-4784, ISSN 1550-6606 
Chowdhury P, Sacks SH, Sheerin NS. (2006). Toll-like receptors TLR2 and TLR4 initiate the innate immune response of the renal tubular epithelium to bacterial products. Clinical Experimental Immunology 145: pp. 346-356, ISSN 1365-2249

Cicco G, Panzera PC, Catalano G, et al. (2005). Microcirculation and reperfusion injury in organ transplantation. Advances in Experimental Medicine and Biology 566: pp. 363373, ISSN 0065-2598

Cosio FG, Pelletier RP, Falkenhain ME, et al. (1997). Impact of acute rejection and early allograft function on renal allograft survival. Transplantation 63: pp. 1611-1615, ISSN 1534-0608

Cosio FG, Pelletier RP, Sedmak DD, et al. (1999). Pathologic classification of chronic allograft nephropathy: pathogenic and prognostic implications. Transplantation 67: pp. 690696, ISSN 1534-0608

Delbridge MS, Shrestha BM, Raftery AT, El Nahas AM, Haylor J. (2007). FTY720 reduces extracellular matrix expansion associated with ischemia-reperfusion induced injury. Transplantation Proceedings pp. 39: 2992-2996, ISSN 0041-1345

Domanski L, Pawlik A, Safranow K, Gryczman M, Sulikowski T, Jabubowska K, Olszewska M, Dziedziejko V, Ostrowski M, Chlubek D, Ciechanowski K. (2009). Circulating adhesion molecules and purine nucleotides during kidney allograft reperfusion. Transplantation Proceedings 41: pp. 40-43, ISSN 0041-1345

Dong X, Swaminathan S, Bachman LA, Croatt AJ, Nath KA, Griffin MD. (2007). Resident dendritic cells are the predominant TNF-secreting cell in early renal ischemiareperfusion injury. Kidney International 71: pp. 619-628, ISSN 0085-2538

Edelstein CL, Shi Y, Schrier RW. (1999). Role of caspases in hypoxia-induced necrosis of rat renal proximal tubules. Journal of American Society of Nephrology 10: pp. 1940-1949, ISSN 1533-3450

El-Achkar TM, Huang X, Plotkin Z, Sandoval RM, Rhodes GJ, Dagher PC. (2006). Sepsis induces changes in the expression and distribution of toll-like receptor 4 in the rat kidney. The American Journal of Physiology Renal Physiology 290: pp. F1034-F1043, ISSN 1522-1466

El Awad B, Kreft B, Wolber EM, Hellwig-Burgel T, Metzen E, Fandrey J, et al. (2000). Hypoxia and interleukin-1beta stimulate vascular endothelial growth factor production in human proximal tubular cells. Kidney International 58: pp. 43-50, ISSN 0085-2538

Furuichi K, Wada T, Iwata Y, Sakai N, Yoshimoto K, Kobayashi Ki K, et al. (2002). Administration of FR167653, a new anti-inflammatory compound, prevents renal ischaemia/reperfusion injury in mice. Nephrology Dialysis and Transplantation 17: pp. 399-407, ISSN 0931-0509

Giral-Classe M, Hourmant M, Cantarovich D, et al. (1998). Delayed graft function of more than six days strongly decreases long-term survival of transplanted kidneys. Kidney International 54: pp. 972-978, ISSN 0085-2538

Hayama T, Matsuyama M, Funao K et al. (2006). Beneficial effect of neutrophil elastase inhibitor on renal warm ischemia- reperfusion injury in the rat. Transplantation Proceedings 38: pp. 2201-2202, ISSN 0041-1345

Halloran PF, Aprile MA, Farewell V, et al. (1988). Early function as the principal correlate of graft survival: a multivariate analysis at 200 cadaveric renal transplants treated 
with a protocol incorporating antilymphocyte globulin and cyclosporine. Transplantation 46: pp. 223-228, ISSN 1534-0608

Halloran PF, Hunsicker LG. (2001). Delayed graft function: stat of the art. The American Journal of Transplantation 1: pp. 115-120, ISSN 1600-6143

Huang LE, Arany Z, Livingston DM, Bunn HF. (1996). Activation of hypoxia-inducible transcription factor depends primarily upon redox-sensitive stabilization of its alpha subunit. The Journal of Biological Chemistry 271: 32253-32259, ISSN 1083-351X

Jayle C, Favreau F, Zhang K, et al. (2007). Comparison of protective effects of trimetazidine against experimental warm ischemia of different durations: early and long-term effects in a pig kidney model. American Journal of Physiology Renal Physiology 292: pp. F1082-1093, ISSN 1522-1466

Kelly KJ, Williams WW Jr. Colvin RB, Meehan SM, Springer TA, Gutierrez-Ramos JC, Bonventre JV. (1996). Intercellular adhesion molecule-1-deficient mice are protected against ischemic renal injury. The Journal of Clinical Investigation 97: pp. 1056-1063, ISSN 0021-9738

Kielar ML, John R, Bennett M, Richardson JA, Shelton JM, Chen L, Jeyarajah DR, Zhou XJ, Zhou H, Chiquett B, Nagami GT, Lu CY. (2005). Maladaptive role of IL-6 in ischemic acute renal failure. Journal of the American Society of Nephrology 16: pp. 3315-3325, ISSN 1533-3450

Kim BS, Lim SW, Li C, Kim JS, Sun BK, Ahn KO, Han SW, Kim J, Yand CW. (2005). Ischemia-reperfusion injury activates innate immunity in rat kidneys. Transplantation 79: pp. 1370-1377, ISSN 1534-0608

Koning OHJ, Ploeg RJ, Van Bockel JH, et al. (1997). Risk factors for delayed graft function in cadaveric kidney transplantation. Transplantation 63: pp. 1620-1638, ISSN 1534-0608

Kuypers DR, Chapman JR, O'Connell PJ, et al. (1999). Predictors of renal transplant histology at three months. Transplantation 67: pp. 1222-1230, ISSN 1534-0608

Kyllönen LE, Salmela KT, Eklund BH, Halme LE, Höckerstedt KA, Isoniemi HM, Mäkisalo HJ, Ahonen J. (2000). Long-term results of 1047 cadaveric kidney transplantations with special emphasis on initial graft function and rejection. Transplant International 13: pp. 122-128, ISSN 1432-2277

Lassen S, Lech M, Römmele C, Mittruecker HW, MaK TW, Anders HJ. (2010). Ischemia reperfusion induces IFN regulatory factor 4 in renal dendritic cells, which suppresses postischemic inflammation and prevents acute renal failure. The Journal of Immunology 185: pp. 1976-1983, ISSN 1550-6606

Li L, Huang L, Sung SS, Vergis AL, Rosin DL, Rose CE, Jr, et al. (2008). The chemokine receptors CCR2 and CX3CR1 mediate monocyte/macrophage trafficking in kidney ischemia-reperfusion injury. Kidney International 74: pp. 1526-1537, ISSN 0085-2538

Li L, Huang L, Sung SS, Lobo PI, Brown MG, Gregg RK, Engelhard VH, Okusa MD. (2007). NKT cell activation mediates neutrophil IFN-gamma production and renal ischemia-reperfusion injury. The Journal of Immunology 178: pp. 5899-5911, ISSN 1550-6606

Li L, Okusa MD. (2006). Blocking the Immune response in ischemic acute kidney injury: the role of adenosine 2A agonists. Nature Clinical Practice Nephrology 2: pp. 432-444, ISSN 1745-8331 
Liew FY, Xu D, Brint EK, O'Neill LAJ. (2005). Negative regulation of Toll-like receptormediated immune responses. Nature Reviews Immunology 5(6): pp. 446-458, ISSN 1474-1733.

Lui SL, Chan KW, Tsang R, Yung S, Lai KN, Chan TM. (2006). Effect of rapamycin on renal ischemia-reperfusion injury in mice. Transplant International 19: pp. 834-839, ISSN 1432-2277

McTaggart RA, Gottlieb D, Brooks J, et al. (2003). Sirolimus prolongs recovery from delayed graft function after cadaveric renal transplantation. American Journal of Transplantation 3: pp. 416-423, ISSN 1600-6143

Meldrum DR, Dinarello CA, Cleveland JC Jr, Cain BS, Shames BD, Meng X, et al. (1998). Hydrogen peroxide induces tumor necrosis factor alpha-mediated cardiac injury by a P38 mitogen-activated protein kinase-dependent mechanism. Surgery 124: pp. 291-296, ISSN 1365-2168

Mizuno S, Nakamura T. (2005). Prevention of neutrophil extravasation by hepatocyte growth factor leads to attenuations of tubular apoptosis and renal dysfunction in mouse ischemic kidneys. American Journal of Pathology 166: pp. 1895-1905, ISSN 0002-9440

Nangaku M, Inagi R, Miyata T, Fujita T. (2008). Hypoxia and hypoxia inducible factor in renal disease. Nephron Experimental Nephrology 110: pp. e1-7, ISSN 1660-2129

Nankivel BJ, Borrows RJ, Fung C L-S, O'Connell PJ, Allean RDM, Chapman JR. (2003). The natural history of chronic allograft nephropathy. The New England Journal of Medicine 349: pp. 2326-2331, ISSN 1533-4406

Nankivell BJ, Chapman JR. (2006). Chronic allograft nephropathy: current concepts and future directions. Transplantation 81: pp. 643-654, ISSN 1534-0608

Ninova D, Covarrubias M, Rea DJ, Park WD, Grand JP, Stegall MD. (2004). Acute nephrotoxocity of tacrolimus and sirolimus in renal isografts: differential intragraft expression of transforming growth factor-beta 1 and alpha-smooth muscle actin. Transplantation 78: pp. 338-344, ISSN 1534-0608.

Noiri E, Doi K, Inagi R, Nangaku M, Fujita T. (2009). Contribution of T lymphocytes to rat renal ischemia/reperfusion injury. Clinical Experimental Nephrology 13: pp. 25-32, ISSN 1437-7799

Novick AC, Hwei HH, Steinmuller D, et al. (1986). Detrimental effect of cyclosporine on initial function of cadaver renal allografts following extended preservation: results of randomized prospective study. Transplantation 42: pp. 154-158, ISSN 1534-0608

Oh DJ, Dursun B, He Z, Lu L, Hoke TS, Ljubanovic D, et al. (2008). Fractalkine receptor (CX3CR1) inhibition is protective against ischemic acute renal failure in mice. The American Journal of Physiology Renal Physiology 294: pp. F264-271, ISSN 1522-1466

Ojo AO, Wolfe RA, Held P, Port FK, Schmouder RL. (1997). Delayed graft function: risk factors and implications for renal allograft survival. Transplantation 63: pp. 968-974, ISSN 1534-0608

O'Neill LAJ. How Toll-like receptors signal: what we know and what we don't know. Current Opinion in Immunology 2006; 18(1): pp. 3-9, ISSN 0952-7915

Perico N, Cattaneo D, Sayegh MH, Remuzzi G. (2004). Delayed graft function in kidney transplantation. Lancet 364: pp. 1814-1827, ISSN 1474-547X 
Roelofs JJ, Rouschop KM, Leemans JC et al. (2006). Tissue-type plasminogen activator modulates inflammatory responses and renal function in ischemia reperfusion injury. The Journal of American Society of Nephrology 17: pp. 131-140, ISSN 1533-3450

Rouschop KM, Roelofs JJ, Claessen N et al. (2005). Protection against renal ischemia reperfusion injury by CD44 disruption. The Journal of American Society of Nephrology 16: pp. 2034-2043, ISSN 1533-3450

Sabbatini M, Uccello F, Serio V, Troncone G, Varone V, Andreucci M, Faga T, Pisani A. (2010). Effects of mycophenolate mofetil on acute ischemia-reperfusion injury in rats and its consequences in the long term. Nephrology Dialysis and Transplantation 25: pp. 1443-1450, ISSN 0931-0509

Saito H, Kitamoto M, Kato K, Liu N, Kitamura H, Uemura K, et al. (2009). Tissue factor and factor V involvement in rat peritoneal fibrosis. Peritoneal Dialysis International 29: pp. 340-351, ISSN 1718-4304

Salceda S, Caro J. (1997). Hypoxia-inducible factor 1alpha (HIF-1alpha) protein is rapidly degraded by the ubiquitin-proteasome system under normoxic conditions. Its stabilization by hypoxia depends on redox-induced changes. The Journal of Biological Chemistry 272: pp. 22642-22647, ISSN 1083-351X

Samuelsson P, Hang L, Wullt B, Irjala H, Svandborg C. (2004). Toll-like receptor 4 expression and cytokine responses in the human urinary tract mucosa. Infection and Immunity 72: pp. 3179-3186, ISSN 1098-5522

Shanley P, Brezis M, Spokes K, Silva P, Epstein F, Rosen S. (1986). Hypoxic injury in the proximal tubule of the isolated perfused rat kidney. Kidney International 29: 10211032, ISSN 0085-2538

Shigeoka AA, Holscher TD, King AJ, Hall FW, Kiosses WB, Tobias PS, Mackman N, McKay DB. (2007). TLR2 is constitutively expressed within the kidney and participates in ischemic renal injury through both MyD88-dependent and -independent pathways. The Journal of Immunology 178: pp. 6252-6258, ISSN 1550-6606

Shoskes DA, Shahed AR, Kim S. (2001). Delayed graft function. Influence on outcome and strategies for prevention. The Urologic Clinics of North America 28: pp. 721-732, ISSN 0094-0143

Shoskes DA, Cecka M. (1998). Deleterious effects of delayed graft function in cadaveric renal transplant recipients independent of acute rejection. Transplantation 66: pp. 16971701, ISSN 1534-0608

Singbartl K, Ley K. (2000). Protection from ischemia-reperfusion induced severe acute renal failure by blocking E-selectin. Critical Care Medicine 28: pp. 2507-2514, ISSN 15300293

Snoejis MJ, van Bijnen A, Swennen E, Haenen GR, Roberts LJ 2nd, Christiaans MH, Peppelenbosh AG, Buurman WA, Ernest van Heurn LW. (2011). Tubular epithelial injury and inflammation after ischemia and reperfusion in human kidney transplantation. Annals of Surgery 253: pp. 598-604, ISSN 1528-1140

Solez K, Vincenti F, Filo RS. (1998). Histopathologic findings from 2-year protocol biopsies from a US multicenter kidney transplant trial comparing tacrolimus versus cyclosporine: a report of the FK506 kidney transplant study group. Transplantation 66: pp. 1736-1740, ISSN 1534-0608 
Soos TJ, Sims TN, Barisoni L, Lin K, Littman DR, Dustin ML, et al. (2006). CX3CR1+ interstitial dendritic cells form a contiguous network throughout the entire kidney. Kidney International 70: pp. 591-596, ISSN 0085-2538

Stegall MD, Park WD, Larson TS, Gloor JM, Cornell LD, Sethi S, Dean PG, Prieto M, Amer H, Textor S, Schwab T, Cosio FG. (2010). The histology of solitary renal allografts at 1 and 5 years after transplantation. The American Journal of Transplantation 10: pp. 110, ISSN 1600-6143

Sutton TA, Mang HE, Camps SB, Sandoval RM, Yoder MC, Molitoris BA. (2003). Injury of the renal microvascular endothelium alters barrier function after ischemia. American Journal of Physiology Renal Physiology 285: pp. F191-F198, ISSN 1522-1466

Sutton TA. (2009). Alteration of microvascular permeability in acute kidney injury. Microvascular research 77: pp. 4-7, ISSN 0026-2862

Thuillier R, Favreaus F, Celhay O, Macchi L, Milin S, Hauet T. (2010) Thrombin inhibition during kidney ischemia-reperfusion reduces chronic graft inflammation and tubular atrophy. Transplantation 90: pp. 612-621, ISSN 1534-0608

Troppman C, Gruessner AC, Gillingham KJ, Sutherland DER, Matas AJ, Gruessner RWG. (1999). Impact of delayed graft function on long-term graft survival after solid organ transplantation. Transplantation Proceedings 31: pp. 1290-1292, ISSN 0041-1345

Thornton MA, Winn R, Alpers CE, Zager RA. (1989). An evaluation of the neutrophil as a mediator of in vivo renal ischemic-reperfusion injury. American Journal of Pathology 135: pp. 509-515, ISSN 1943-7722

Tsuboi N, Yoshikai Y, Matsuo S, Kikuchi T, Iwami K, Nagai Y, Takeuchi O, Akira S, Matsuguchi T. (2002). Roles of toll-like receptors in C-C chemokine production by renal tubular epithelial cells. The Journal of Immunology 169: pp. 2026-2033, ISSN 1550-6606

Yang CW, Hung CC, Wu MS, Tian YC, Chang CT, Pan MJ, Vandewalle A. (2006). Toll-like receptor 2 mediates early inflammation by leptospiral outer membrane proteins in proximal tubule cells. Kidney International 69: pp. 815-822, ISSN 0085-2538

Zhang ZX, Wang S, Huang X, Min WP, Sun H, Liu W, et al. (2008). NK cells induce apoptosis in tubular epithelial cells and contribute to renal ischemia-reperfusion injury. The Journal of Immunology 181: pp. 7489-7498 ISSN 1550-6606

Zhou J, Brune B. (2006). Cytokines and hormones in the regulation of hypoxia inducible factor-1alpha (HIF-1alpha). Cardiovascular and Hematological Agents in Medicinal Chemistry 4: pp. 189-197, ISSN 1871-5257

Williams P, Lopes H, Britt D, Chan C, Ezrin A, Hottendorf R. (1997). Characterization of renal ischemia-reperfusion injury in rats. Journal of Pharmacological and Toxicological Methods 37: pp. 1-7, ISSN 1056-8719

Wolfs TG, Buurman WA, van Schadewijk A, de Vries B, Daemen MA, Hiemstra PS, van't Veer C. (2002). In vivo expression of toll-like receptor 2 and 4 by renal epithelial cells: IFN-gamma and TNF-alpha mediated up-regulation during inflammation. The Journal of Immunology 168: pp. 1286-1293, ISSN 1550-6606

Woolfson RG, Millar CGM, Neild GH. (1994). Ischaemia and reperfusion injury in the kidney: current status and future direction. Nephrology Dialysis and Transplantation 9(11): pp. 1529-1531, ISSN 0931-0509 
Wu H, Chen G, Wyburn KR, Yin J, Bertolino P, Eris JM, Alexander SI, Sharland AF, Chadban SJ. (2007). TLR4 activation mediates kidney ischemia/reperfusion injury. The Journal of Clinical Investigation 117: pp. 2847-2859, ISSN 0021-9738 


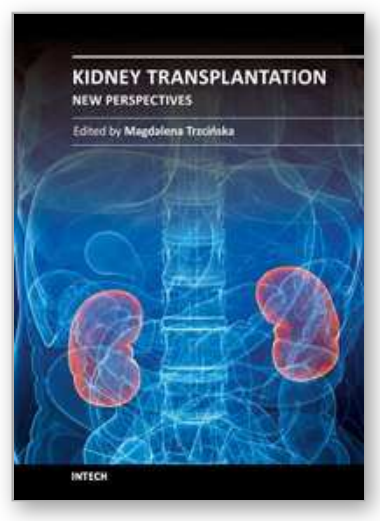

\author{
Kidney Transplantation - New Perspectives \\ Edited by Dr Magdalena Trzcinska
}

ISBN 978-953-307-684-3

Hard cover, 334 pages

Publisher InTech

Published online 23, August, 2011

Published in print edition August, 2011

Although many years have passed since the first successful kidney transplantation, the method, although no longer considered a medical experiment, is still perceived as controversial and, as such, it triggers many emotions and thatâ $\epsilon^{\mathrm{TM}} \mathrm{S}$ why conscious educational efforts are still needed for kidney transplantation, for many people being the only chance for an active lifestyle and improved quality of life, to win common social acceptance and stop triggering negative connotations. Apart from transplantation controversies piling up over years transplantologists also have to face many other medical difficulties. The chapters selected for this book are of high level of content, and the fact that their authors come from many different countries, and sometimes even cultures, has facilitated a comprehensive and interesting approach to the problem of kidney transplantation. The authors cover a wide spectrum of transplant-related topics.

\title{
How to reference
}

In order to correctly reference this scholarly work, feel free to copy and paste the following:

Valquiria Bueno (2011). The Impact of Ischemia and Reperfusion Injury in Kidney Allograft Outcome, Kidney Transplantation - New Perspectives, Dr Magdalena Trzcinska (Ed.), ISBN: 978-953-307-684-3, InTech, Available from: http://www.intechopen.com/books/kidney-transplantation-new-perspectives/the-impact-ofischemia-and-reperfusion-injury-in-kidney-allograft-outcome

\section{INTECH}

open science | open minds

\author{
InTech Europe \\ University Campus STeP Ri \\ Slavka Krautzeka 83/A \\ 51000 Rijeka, Croatia \\ Phone: +385 (51) 770447 \\ Fax: +385 (51) 686166 \\ www.intechopen.com
}

\author{
InTech China \\ Unit 405, Office Block, Hotel Equatorial Shanghai \\ No.65, Yan An Road (West), Shanghai, 200040, China \\ 中国上海市延安西路65号上海国际贵都大饭店办公楼 405 单元 \\ Phone: +86-21-62489820 \\ Fax: $+86-21-62489821$
}


(C) 2011 The Author(s). Licensee IntechOpen. This chapter is distributed under the terms of the Creative Commons Attribution-NonCommercialShareAlike-3.0 License, which permits use, distribution and reproduction for non-commercial purposes, provided the original is properly cited and derivative works building on this content are distributed under the same license. 